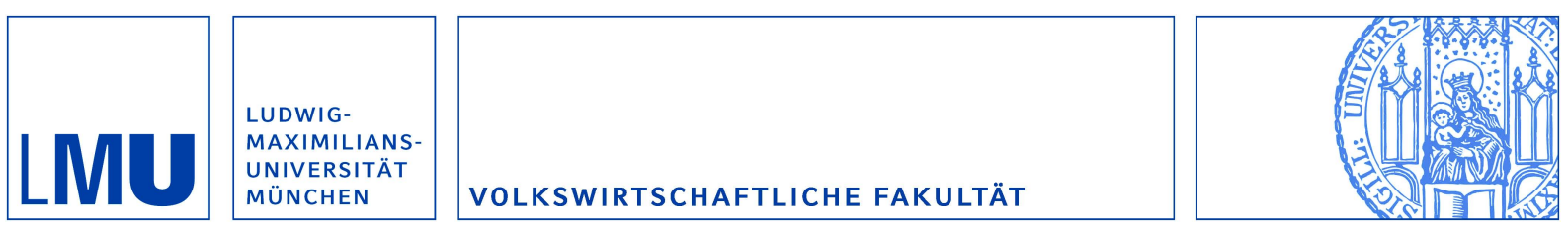

Langenmayr, Dominika:

Voluntary Disclosure of Evaded Taxes - Increasing Revenues, or Increasing Incentives to Evade?

Munich Discussion Paper No. 2014-41

Department of Economics

University of Munich

Volkswirtschaftliche Fakultät

Ludwig-Maximilians-Universitäł München

Online at https://doi.org/10.5282/ubm/epub.21359 


\title{
Voluntary Disclosure of Evaded Taxes - Increasing Revenues, or Increasing Incentives to Evade?
}

\author{
Dominika Langenmayr* \\ University of Munich
}

August 12, 2014

\begin{abstract}
Many countries apply lower fines to tax evading individuals when they voluntarily disclose the tax evasion they committed. I model such voluntary disclosure mechanisms theoretically and show that while such mechanisms increase the incentive to evade taxes, they nevertheless increase tax revenues net of administrative costs. I then test the effects of voluntary disclosure in two separate empirical analyses. First, I confirm that voluntary disclosure mechanisms increase tax evasion, using the introduction of the 2009 offshore voluntary disclosure program in the U.S. for identification. Second, I quantify the tax revenues of voluntary disclosures by considering how some state-level governments in Germany bought whistle-blower data from foreign bank employees, thereby increasing the detection probability and the usage of voluntary disclosures.
\end{abstract}

Keywords: Tax evasion, voluntary disclosure, self-reporting

JEL Classification: H26, K42, H24

*This paper was presented at the 2014 NBER Trans-Atlantic Public Economic Seminar in Vienna. I thank all participants, especially the discussants Joel Slemrod and Stephanie Sikes, for very helpful comments and discussion. I am also grateful to Nadja Dwenger, Andreas Haufler, Gareth Myles and seminar participants in Munich for further helpful comments. My thanks also go to Lisa Eßbaumer for excellent research assistance. E-mail: dominika.langenmayr@econ.lmu.de. 


\section{Introduction}

Households worldwide hold about $8 \%$ of their total financial wealth, almost U.S.-\$ 6 trillion, in tax havens (Zucman, 2013). Correspondingly, tax authorities forego high tax revenues: Estimates for the United States show that personal income tax evasion via offshore accounts may cost around $\$ 70$ billion annually (Gravelle, 2009). The need for tax revenues in the wake of the financial crisis has now rekindled governments' efforts to curb such income tax evasion.

Principally, governments can fight tax evasion by individuals who hold their wealth offshore in two ways. First, they can negotiate with tax havens to share information regarding foreigners' accounts. An example is the recent agreement between the United States and Switzerland forcing Swiss banks to provide information on accounts owned by U.S. citizens. However, such treaties are not very effective, as tax evaders rather shift their funds to different tax havens instead of repatriating them (Johannesen and Zucman, 2014). Second, governments can set incentives for individual taxpayers to declare foreign wealth and the tax evaded on it.

Many countries incentivize individuals to come clean by a "voluntary disclosure" mechanism. Usually, the prerequisite is to report all foreign asset holdings. The income on these assets is then taxed retroactively at the standard tax rate, but no or a reduced fine is levied. Only individuals not yet under investigation for tax evasion can profit from such programs. Voluntary disclosure programs exist in many countries (see Table 1 for an overview), and are often part of the general law and for an unlimited period. However, some commentators fear that the option of voluntary disclosure increases the incidence of tax evasion, as these programs offer the possibility to escape high punishments if individuals decide that the probability of detection has increased.

\section{[Table 1 about here.]}

The economic literature has so far barely studied voluntary disclosure programs. Using both a theoretical model and empirical tests, the paper aims to shed some light on this topic. First, I ask how the existence of a voluntary disclosure program affects individuals' tax evasion decision. In both the theoretical model and the empirical test I show that the existence of such a program increases tax evasion. Second, I consider the government's point of view, studying whether the tax authorities should offer voluntary disclosure, despite the increase in tax evasion it causes. In my model, governments 
should offer voluntary disclosure only when a disclosure lowers the administrative costs related to assessing taxes of evaders. I then confirm the importance of administrative costs in a survey of German competent local tax authorities. In a second empirical test I quantify the revenues brought in by voluntary disclosure in Germany. Lastly, I analyze how governments should fine tax evaders after a voluntary disclosure.

In more detail, my theoretical model frames tax evasion as a rational choice of individuals that bear a moral (psychic) cost when evading taxes. There is ex-ante uncertainty about the probability of being caught and fined, and individuals have the possibility to voluntarily disclose the tax evasion they committed after the detection probability is revealed. In equilibrium, the individuals with the lowest moral cost will evade taxes, those with intermediate moral costs will first evade taxes but voluntarily disclose later when the detection probability is high, and those with the highest moral costs will never evade taxes. In this model I show that the existence of voluntary disclosure increases the number of individuals who evade taxes. This result arises as voluntary disclosure allows individuals to better differentiate their actions according to the detection probability.

I later test this result empirically, using the introduction of the first Offshore Voluntary Disclosure Program in the U.S. in 2009 for identification. Employing a synthetic control approach, I analyze how U.S. deposits in offshore havens have changed compared to deposits from other countries. This analysis confirms that the existence of a voluntary disclosure program indeed increases tax evasion, in line with the theoretical model.

I also model how the government should employ voluntary disclosure. In the model, voluntary disclosure increases net tax revenue if there are administrative costs of fining tax evaders in the absence of a voluntary disclosure. I confirm the importance of these administrative cost savings in a survey among German competent local tax authorities. In the model, government optimally set voluntary disclosure fines by trading off higher tax evasion with these savings in administrative costs. In a last step, I study shocks to detection probabilities in Germany to gauge the additional revenue of a voluntary disclosure. My estimates suggest that one voluntary disclosure brings in around $€ 26,000$ on average.

Several strands of literature are relevant to this paper. First, there is a large literature on tax evasion by individuals (see Slemrod (2007) for an overview). The theory goes back to Allingham and Sandmo (1972) and Yitzhaki (1974), who model tax eva- 
sion analogous to portfolio choice. Sandmo (2005) provides a review of this line of literature. Despite the obvious difficulties to measure tax evasion, there is also a large empirical literature, which Alm (2012) summarizes.

To my knowledge, no paper studies a voluntary disclosure program as described above. However, there is some literature on tax amnesties, which are short-run programs (often about three months long) that usually do not fine tax evaders. Also in contrast to voluntary disclosures, tax amnesties often include those already under investigation for tax evasion and allow only a partial reporting of prior tax evasion. In this literature, Malik and Schwab (1991) propose a model with uncertainty about the disutility from tax evasion to explain why individuals take up the offer of a tax amnesty (which they never would in the standard Allingham-Sandmo model). Alm and Beck (1990) set up a prospect theory model in which the share of evaded tax that is declared in the amnesty is the main decision parameter. Stella (1991) discusses the interaction between future enforcement and tax amnesties, predicting that amnesties are unlikely to generate additional revenue. Alm and Beck (1993) confirm this result empirically in a time-series analysis. ${ }^{1}$

Closer to this paper is an analysis by Andreoni (1991), who asks how a "permanent tax amnesty" (in effect, a voluntary disclosure program in the sense discussed above) would affect the efficiency and equity of the tax system. He proposes a model in which people use the amnesty when shocks to their consumption make them unwilling to bear the risk of audit. In this model, the tax amnesty acts similar to social insurance, allowing those in bad luck to eliminate some of their risk. He does not consider administrative costs or the optimal fine set by the government, but assumes (as common in this

\footnotetext{
${ }^{1}$ Other papers have studied behavioural responses of individuals to temporary decreases of other taxes. For example, Agarwal et al. (2013) show very large behavioral responses to sales tax holidays, brief periods in which sales taxes are reduced or eliminated. They find little evidence of substitution across products or over time. In contrast, Cole (2009) estimates that sales tax revenues decrease by up to $8 \%$ during tax holiday months. Studying a stamp duty holiday in the UK, Besley et al. (2014) similarly find that the tax holiday mostly leads to short-term retiming of transactions. However, due to the specific situation of prior tax evasion, it is unclear how well these results transfer to voluntary disclosure.
} 
literature) that there is no fine after a disclosure. ${ }^{2}$

In all, voluntary disclosure programs with their current characteristics (e.g. requiring full disclosure, and having a specifically chosen fine as their most prominent characteristic) have so far been an understudied aspect of tax evasion. This paper aims to shed some light on them. Section 2 provides the theoretical model. Section 3 empirically tests some aspects of voluntary disclosure. Section 4 concludes.

\section{$2 \quad$ Model}

\subsection{Framework}

To illustrate the consequences of voluntary disclosure, I set up a model in which individuals may evade capital income taxes by transferring money to an offshore account. The government can set incentives for tax evaders to come clean by offering them the possibility to voluntarily disclose the tax evasion they committed. Offshore income indicated in a voluntary disclosure is then taxed, and fined at a rate chosen by the government.

From the government's point of view, a voluntary disclosure has two main advantages. First, it detects tax evasion that it potentially would not have exposed otherwise. Second, a voluntary disclosure saves the government administrative costs, such as the cost of the time spent collecting information from less-than-cooperative offshore banks. ${ }^{3}$

Individuals in the model face ex-ante uncertainty about detection probabilities. This uncertainty reflects, for example, that there is a certain probability that an informant offers the government information about offshore accounts. Figure 1 clarifies the real-world significance of changes in detection probabilities using the example of Germany, which has bought whistle-blower information offered by former bank employees

\footnotetext{
${ }^{2}$ Some further papers study the optimal self-reporting of violations of the law in a non-tax context. A first contribution is Kaplow and Shavell (1994), who show that self-reporting increases welfare as it saves enforcement resources and reduces uncertainty for individuals facing potential sanctions. Their model has been extended to consider ex-post asymmetric information (Feess and Heesen, 2002) or self-reporting at different stages of an investigation (Feess and Walzl, 2005).

${ }^{3}$ Tax lawyers and tax authorities have confirmed in private discussions that a voluntary disclosure often has several hundred to thousand pages, as the individual not only has to disclose all capital income over a certain period, but also proof that the disclosure is complete.
} 
Figure 1: Voluntary Disclosures per Quarter in Germany

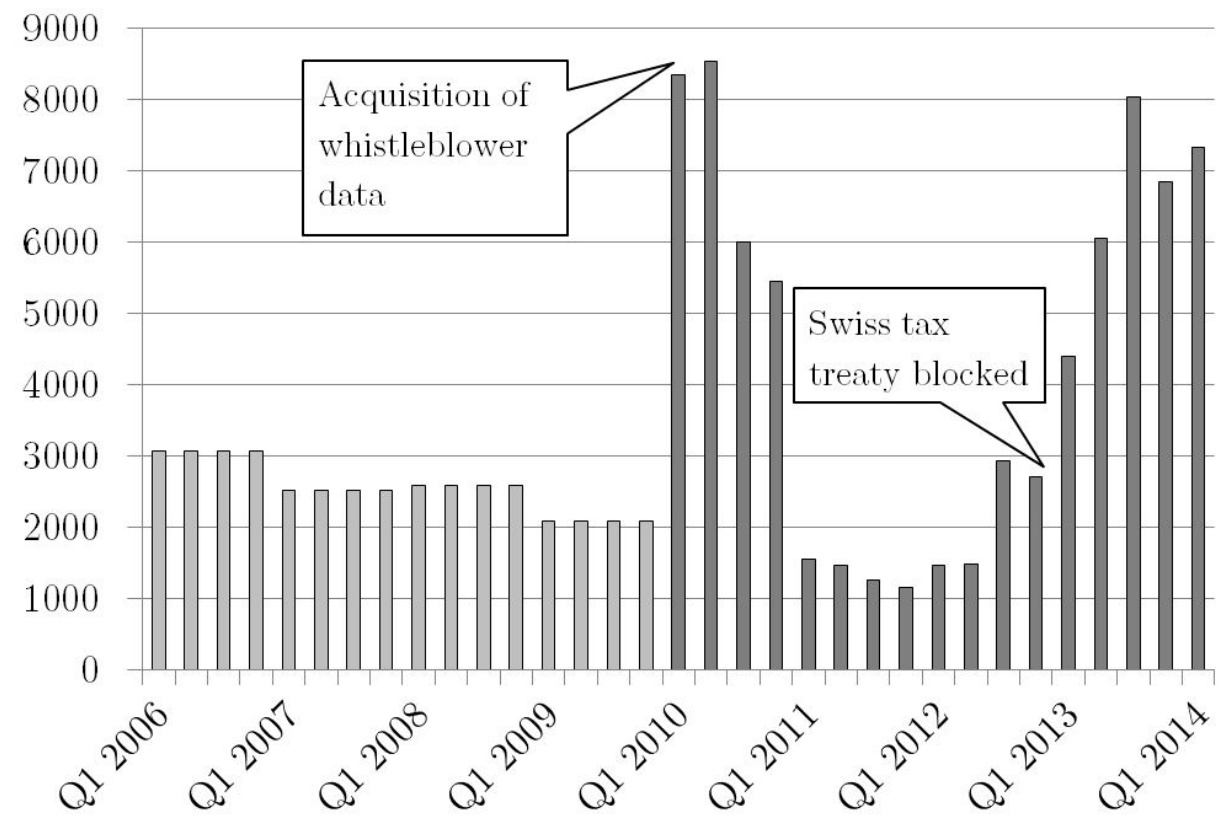

Voluntary Disclosures per quarter in Germany, Q1 2006 - Q1 2014. Graph based on information from state finance ministries, data for 2006-2009 is extrapolated based on information for Lower Saxony and Schleswig-Holstein.

in tax havens at a large scale. The acquisition of such data from February 2010 onward was widely discussed in the media. In 2011, it emerged that Germany and Switzerland had negotiated a tax treaty under which undeclared accounts of German nationals in Switzerland would be subject to a one-time tax payment. This single tax payment was supposed to be collected anonymously and to exempt the account holder from prosecution for tax evasion committed in the past. However, in November 2012, the upper house of the German parliament did not pass this tax treaty, thus making voluntary disclosure again the only possibility to come clean on past tax evasion. ${ }^{4}$

The model reflects such changes in the underlying detection probabilities. With probability $q$, a high detection probability $p_{H}$ occurs (e.g. because the government receives whistle-blower information). Correspondingly, with probability $1-q$ there is no leak and the detection probability is low $\left(p_{L}\right)$. This uncertainty not only reflects the real-world facts described above, but is also necessary for the model, as rational

\footnotetext{
${ }^{4}$ See Pfisterer (2013) for an overview of these developments.
} 
individuals will only voluntarily disclose tax evasion they optimally chose to commit earlier if they have received new information. ${ }^{5}$

Not all individuals have the same willingness to evade taxes. Kleven et al. (2011) show that even among Danish tax payers who self-report their income (and thus have the opportunity to evade taxes), less than $40 \%$ actually evade taxes. I model such heterogeneity among individuals with a moral cost of tax evasion $\left(\alpha_{i} \in[0 ; A]\right)$, which is specific to the individual. In equilibrium, there will be three different groups of individuals: First, a group of "non-evaders", who have high moral costs and never evade taxes; second, "disclosers", who evade taxes but voluntarily disclose if the high detection probability is drawn; and lastly "evaders", who evade even when the high detection probability occurs.

Individuals decide about tax evasion and voluntary disclosure by maximizing their expected utility. ${ }^{6}$ I assume risk neutral individuals, whose utility is

$$
U_{i}=y-\tau_{i s}-1 \alpha_{i}
$$

$y$ is the pre-tax capital income, $\tau_{i s}$ is the tax (and fine) payment that depends on individual $i$ 's tax evasion and disclosure decisions as well as the state of the world $s$, and $\mathbb{1}$ is an indicator function that is equal to one if the individual evades taxes and zero otherwise. Due to the linear structure of the utility function, it is never optimal to declare a share of the true income.

In the main model, I assume risk neutral, heterogeneous individuals as these assumptions allow a tractable model that fits well to the stylized facts described above. To provide robustness and make sure that risk averse individuals would not change the main implications from the model, Appendix 1 provides a model that focusses on

\footnotetext{
${ }^{5}$ I treat the two potential detection probability as exogenous, as the government can affect them only in the medium to long term. Tax authorities usually do not hire short-term workers as employees have to handle sensitive tax data, and training new employees takes time. Moreover, strong job protection rules in the public sector make short-term adjustments very costly. Other short term actions, such as negotiating new information sharing agreements with tax havens, can be understood as an occurrence of $p_{H}$.

${ }^{6}$ There is also a part of the literature that does not rely on expected utility theory. Alm et al. (1992) show in an experiment that some individuals overweight the low probability of audit. Dhami and Al-Nowaihi (2010) model such behavior using prospect theory and predict a positive relationship between tax rates and tax evasion. However, when testing whether expected utility theory or prospect theory provide a better explanation of individuals' behavior regarding tax evasion, King and Sheffrin (2002) find experimental evidence in favor of expected utility theory.
} 
the tax evasion decision of risk averse individuals in the presence of a voluntary disclosure mechanism. In that model, every individual evades some (but not all) tax. In the presence of voluntary disclosure, every individual decides to evade more taxes than in the benchmark case without voluntary disclosure. In sum, the main results concerning aggregate tax evasion and tax revenues are very similar to the main model.

Individuals are liable to pay taxes at the statutory rate $t$. They can evade this tax by hiding their money in an offshore account and not declaring the income derived from it. If the tax authorities detect the tax evasion, the individual pays a fine $F>1$ that is proportional to the evaded tax. I treat the fine for tax evasion, $F$, as exogenous, assuming that it is set in an appropriate relation to punishments for other crimes. ${ }^{7}$

The government may allow voluntary disclosures of prior tax evasion. As is common practice, a voluntary disclosure requires that the individual reports all income on which he evaded taxes. Preparing a voluntary disclosure is costly for the individual, as he has to collect all information necessary to assess his taxes. I model this with a compliance $\operatorname{cost} c^{c}$ that arises when preparing a voluntary disclosure. The individual has to pay taxes on the income declared in the voluntary disclosure retroactively. Additionally, the government imposes a fine $f(1 \leq f \leq F)$, which is proportional to the evaded tax. The government sets this fine to maximize revenues. Moreover, I assume that a voluntary disclosure clears the conscience of the individual, i.e. that after a voluntary disclosure the individual no longer has moral qualms about the tax evasion he committed earlier.

The government incurs administrative costs $c^{a}$ for each tax evading individual, as it checks and audits the tax return and collects information from offshore banks. For the tax authorities, these costs are significantly higher than the costs that a taxevading individual incurs when preparing a voluntary disclosure: The tax authorities have to investigate to detect all foreign accounts and asset holdings, and then have to obtain detailed information on the movements of funds from less-than-cooperative offshore banks. In contrast, the individual himself either has all this information already available, or can (as the account holder) easily request it from his banks.

Voluntary disclosure will only take place in equilibrium if there are rents to share, i.e. when the costs of preparing a voluntary disclosure $\left(c^{c}\right)$ are sufficiently lower than the administrative costs of fining tax evaders $\left(c^{a}\right)$. On the other side, administrative costs

\footnotetext{
${ }^{7}$ Since the analysis of Kolm (1973), it is well known that with positive marginal costs of auditing, the government optimally sets the fine for tax evasion to the maximum level that is in line with moral and legal constraints. This is the implicit assumption in the model presented here.
} 
Figure 2: Sequence of events

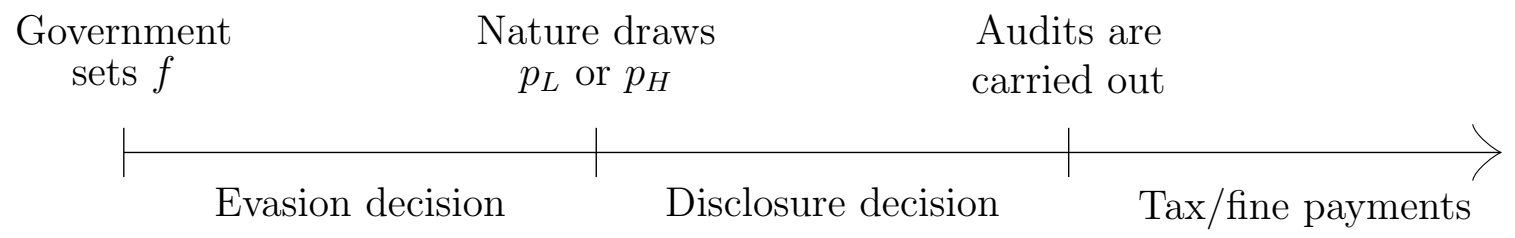

may not be so high that fining tax evaders is no longer worthwhile for the government. To make sure that these conditions are met, I assume that

$$
\frac{c^{c}}{(1-q)\left(p_{h}-p_{L}\right)} \leq c^{a}<\text { Fty } .
$$

This condition assures that individuals are willing to disclose (left part), and that the government is willing to fine evaders despite the administrative cost (right part).

Given these tax and fine payments and compliance cost, an individual's utility is

$$
\begin{aligned}
U^{t} & =y-t y & & \text { if no evasion, } \\
U^{0} & =y-\alpha_{i} & & \text { if evasion not detected, } \\
U^{F} & =y-F t y-\alpha_{i} & & \text { if evasion detected, } \\
U^{v d} & =y-f t y-c^{c} & & \text { if evasion voluntarily disclosed. }
\end{aligned}
$$

Knowing these different outcomes, individuals decide about tax evasion anticipating the full sequence of events. The government, in turn, takes individuals' decisions into account and sets the voluntary disclosure fine accordingly.

Figure 2 describes the stages of the game in more detail. First, the government sets the voluntary disclosure fine $f$. In the second stage, individuals decide whether they want to evade taxes. They anticipate that nature will draw the detection probability $p$ in the next stage. After the detection probability is revealed, individuals may have the option to voluntarily disclose the tax evasion they committed. Lastly, the government audits some taxpayers, and individuals accordingly pay taxes and fines.

\subsection{Benchmark Without Voluntary Disclosure}

As a benchmark, consider first the case when voluntary disclosure is not possible. Individuals then base their evasion decision on the expected detection probability, $\bar{p}$, with $\bar{p}=q p_{H}+(1-q) p_{L}$. Comparing the expected utility when evading taxes 
$\left(\bar{p} U^{F}+(1-\bar{p}) U^{0}\right)$ with the utility if they pay all taxes $\left(U^{t}\right)$ shows that individuals with a moral cost $\alpha_{i}<\alpha^{0}$ evade taxes, with $\alpha^{0}$ given by

$$
\alpha^{0}=t y(1-\bar{p} F)
$$

The number of evaders is higher the higher the potential gain from tax evasion $(t y)$, and lower the higher the expected fine $(\bar{p} F t y) .{ }^{8}$

For later use, tax revenues net of administrative costs, $T^{0}$, are

$$
T^{0}=\int_{0}^{\alpha^{0}} \bar{p}\left(F t y-c^{a}\right) d G\left(\alpha_{i}\right)+\int_{\alpha^{0}}^{A} t y d G\left(\alpha_{i}\right)
$$

The first term denotes the taxes and fines net of administrative costs that the tax authorities collect from evaders; the second term are taxes that non-evaders pay.

\subsection{Voluntary Disclosure}

A voluntary disclosure implies that an individual reports all income on which he evaded taxes to the authorities. In most countries voluntary disclosures are associated with a fine (see Table 1 for details). The voluntary disclosure fine $f \geq 1$ is lower than the fine for tax evasion $(f \leq F)$, and in some countries no fine is levied $(f=1)$.

If nature draws the low detection probability, it cannot be rational to voluntarily disclose - after all, the same individual chose to evade taxes when it was still unclear whether the low or the high detection probability would arise. However, if nature draws the high detection probability, evaders with relatively high moral costs of tax evasion may opt for a voluntary disclosure, preferring a certain, but lower, fine payment and clear conscience over the tax saving with the risk of a high fine if evasion is detected. In particular, individuals will disclose if their utility after a disclosure $\left(U^{v d}\right)$ is higher than the expected utility if they evade $\left(p_{H} U^{F}+\left(1-p_{H}\right) U^{0}\right)$. Thus, individuals disclose when their moral cost are $\alpha_{i} \geq \alpha^{v d}$, with

$$
\alpha^{v d}=t y\left(f-p_{H} F\right)+c^{c}
$$

More individuals voluntarily disclose when the fine associated with voluntary disclosure is low. But even when there is no fine after a voluntary disclosure $(f=1)$, not all

\footnotetext{
${ }^{8}$ As common in the literature I assume that $\bar{p} F<1$, i.e. that tax evasion is worthwhile in expectation.
} 
Figure 3: Behavior of individuals with different moral costs $\alpha_{i}$.

Without voluntary disclosure program:

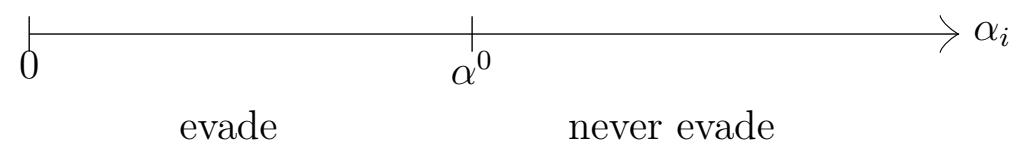

With voluntary disclosure program:

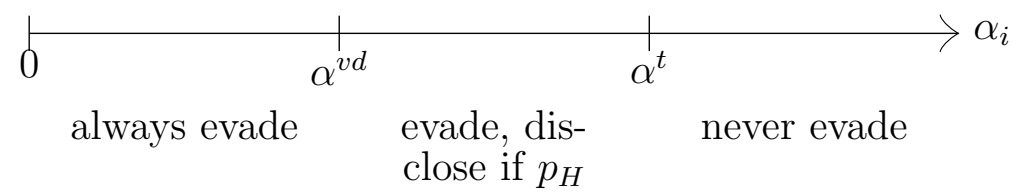

individuals will voluntarily disclose if the detection probability $p_{H}$ is sufficiently low that there still is an expected gain from tax evasion. Higher compliance costs associated with preparing the voluntary disclosure also make it less attractive.

Even with the voluntary disclosure possibility, not everyone evades taxes. In particular, individuals with moral costs $\alpha_{i} \geq \alpha_{t}$ choose no evasion over evading and disclosing when the detection probability is high, with

$$
\alpha^{t}=t y \frac{1-q f-(1-q) p_{L} F}{1-q}-\frac{q}{1-q} c^{c}
$$

$\alpha^{t}$ is larger than $\alpha^{v d}$ when $t y\left[1-f+(1-q)\left(p_{H}-p_{L}\right) F\right]<c^{c}$. After deriving the equilibrium fine it will become clear that this condition holds when the compliance costs of the individual preparing the voluntary disclosure are sufficiently lower than the administrative costs of the tax authority, i.e. when (2) is met. Under this assumption, Figure 3 shows how the different types of individuals behave in equilibrium depending on whether voluntary disclosure is possible or not.

Ex ante, i.e. before the detection probability is revealed, expected tax revenues net of administrative costs when voluntary disclosure is possible are

$T=\int_{0}^{\alpha^{v d}} \bar{p}\left(F t y-c^{a}\right) d G\left(\alpha_{i}\right)+\int_{\alpha^{v d}}^{\alpha^{t}}\left[q f t y+(1-q) p_{L}\left(F t y-c^{a}\right)\right] d G\left(\alpha_{i}\right)+\int_{\alpha^{t}}^{A} t y d G\left(\alpha_{i}\right)$.

The first term refers to the revenue collected from evaders, the second term to the expected revenue from those who voluntarily disclose when the detection probability 
is high, and the last term to the revenue collected from non-evaders. Note that no administrative costs arise after a voluntary disclosure, as the disclosure has to contain all information necessary for assessing the tax liability. ${ }^{9}$

The government sets the fine that applies after a voluntary disclosure to maximize the expected tax revenues. Assuming that there is a mass $M$ of taxpayers with moral $\operatorname{costs} \alpha_{i}$ distributed uniformly in the interval $[0, A]$, Eq. (7) can be rewritten as

$$
T=\bar{p}\left(F t y-c^{a}\right) \frac{\alpha^{v d} M}{A}+\left[q f t y+(1-q) p_{L}\left(F t y-c^{a}\right)\right] \frac{\left(\alpha^{t}-\alpha^{v d}\right) M}{A}+t y \frac{\left(A-\alpha^{t}\right) M}{A},
$$

with $\alpha^{v d}$ and $\alpha^{t}$ given by Eqs. (5) and (6). Maximizing Eq. (8) over $f$ yields the optimal voluntary disclosure fine $f^{*}$,

$$
f^{*}=1+(1-q)\left(p_{H}-p_{L}\right) F-\frac{(1-q)\left(p_{H}-p_{L}\right) c^{a}+c^{c}}{2 t y} .
$$

The optimal fine for voluntary disclosure is higher when the fine for tax evasion $(F)$ is higher, and lower when the administrative costs associated with tax evasion or the compliance costs associated with preparing the voluntary disclosure are higher. When the difference between the detection probabilities in the two states of the world is large, the voluntary disclosure fine is higher, because the difference in detection probabilities increases the incentive for individuals to come clean.

For further interpretation, consider the cutoffs $\alpha^{v d^{*}}$ and $\alpha^{t^{*}}$ as a function of the underlying parameters:

$$
\begin{aligned}
\alpha^{v d^{*}} & =t y(1-\bar{p} F)-\frac{1}{2}(1-q)\left(p_{H}-p_{L}\right) c^{a}+\frac{1}{2} c^{c} \\
\alpha^{t^{*}} & =t y(1-\bar{p} F)+\frac{1}{2} q\left(p_{H}-p_{L}\right) c^{a}-\frac{1}{2} \frac{q}{1-q} c^{c} .
\end{aligned}
$$

Clearly, when there are no administrative costs or compliance costs, $\alpha^{v d^{*}}=\alpha^{t^{*}}(=$ $\alpha^{0}$ ), i.e. the revenue-maximizing government sets the fine so high that voluntary disclosure is not attractive for any evader. Comparing (10) and (11) shows that for voluntary disclosure to take place in equilibrium, it has to hold that $c^{c} \leq c^{a}(1-q)\left(p_{h}-p_{L}\right)$, as assumed above in (2).

Next, consider how the existence of a voluntary disclosure mechanism affects the tax evasion decision. Comparing $\alpha^{t}$ with $\alpha^{0}$ from the benchmark model without voluntary disclosure yields the following proposition:

\footnotetext{
${ }^{9}$ In principle, a much lower administrative cost also arises after a voluntary disclosure or when assessing the tax returns of non-evaders. This cost is here normalized to zero.
} 
Proposition 1 A voluntary disclosure program with an optimally set fine in the presence of administrative costs increases the number of individuals that evade taxes.

Proof. Proof by contradiction: Assume $\alpha^{t}<\alpha^{0}$. Then, from Eqs. (3) and (11),

$$
0>\left(p_{H}-p_{L}\right) c^{a}-\frac{c^{c}}{1-q},
$$

which is a contradiction whenever parameters are such that voluntary disclosure takes place in equilibrium (i.e. when condition (2), which followed from comparing $\alpha^{v d^{*}}$ and $\alpha^{t^{*}}$, holds).

To understand this result, consider how voluntary disclosure affects the tax evasion decision. Voluntary disclosure can be interpreted as an option that an individual may exercise when the detection probability proves to be high. Without this option (i.e. in an economy without voluntary disclosure), individuals come to a decision about evading taxes based on the expected probability of detection, $\bar{p}$. In contrast, if voluntary disclosure is possible, individuals anticipate that they can voluntarily disclose when the detection probability is high and thus decide about tax evasion based on the low detection probability $p_{L}$ and the voluntary disclosure fine $f$. In the extreme case of no voluntary disclosure fine $(f=1)$, they evade as if the detection probability was $p_{L}$ for sure. As more people evade taxes when the detection probability is lower, the possibility of voluntary disclosure increases the number of people who evade taxes to start with.

For a revenue-maximizing government, the higher tax evasion when a voluntary disclosure program exists seems to be an argument against introducing such a program. However, voluntary disclosure has several other effects on tax revenues. With voluntary disclosure, more individuals pay tax (and the low fine $f$ ) in the state of the world with the high detection probability, and administrative costs are lower. In contrast, in the low detection probability state, is has clear negative effects as there is more evasion but no voluntary disclosures take place.

To see the overall effect on tax revenues, I compare the equilibrium tax revenues $T^{*}$ (derived by inserting the optimal fine $f^{*}$ and $\alpha^{v d^{*}}$ and $\alpha^{t^{*}}$ in Eq. 8) with Eq. (4), assuming a uniform distribution of $\alpha_{i}$ also in this case. This shows

$$
\begin{aligned}
& T^{*}>T^{0} \Leftrightarrow \\
& \frac{\left[c^{c}-c^{a}\left(p_{h}-p_{L}\right)(1-q)\right]^{2} q}{4(1-q)}>0 .
\end{aligned}
$$


When administrative costs are positive, (12) is always fulfilled. Then, the existence of voluntary disclosure increases tax revenues net of administrative costs. The voluntary disclosure program offers the government a way to share into the rents that arise because individuals have a lower cost of preparing the information for assessing previously evaded taxes than the tax authorities themselves. Thus, the government decides to use voluntary disclosure despite the increase in tax evasion it causes.

When there are no administrative costs $\left(c^{a}=0\right), T^{*}=T^{0} \cdot{ }^{10}$ In this case, the government optimally sets the voluntary disclosure fine so high that no voluntary disclosure takes place in equilibrium (see Eqs. 11 and 10). This behavior is optimal as an attractive voluntary disclosure program (i.e. a program with a fine sufficiently low that there is some uptake) would increase tax evasion, without the corresponding benefit of lower administrative costs.

The following proposition summarizes these results:

Proposition 2 If and only if there are administrative costs when assessing evaded taxes, the existence of a voluntary disclosure program raises expected tax revenues net of administrative costs.

Proof. See Eq. (12).

Intuitively, as long as administrative costs are positive, the voluntary disclosure mechanism generates efficiency gains in terms of reduced collection costs. The government can increase these efficiency gains by drawing people into the voluntary disclosure scheme, but this implies setting a low fine and foregoing additional tax revenue. In addition, a low fine implies that evasion becomes more attractive ex ante.

\subsection{Administrative Costs}

Proposition 2 has shown that the government should implement a voluntary disclosure program if such a program is associated with lower administrative costs. If this is not the case, the government should not use this instrument (in the model, the government sets the fine such that no individual voluntarily discloses).

\footnotetext{
${ }^{10}$ When $c^{a}=0$, it follows from $(2)$ that $c^{c}=0$ as it cannot be more expensive for the individual to gather information on his tax evasion than for the tax authorities.
} 
The crucial assumption is that the administrative costs for the tax authorities are significantly lower when they assess evaded taxes on the basis of a voluntary disclosure, compared to a situation in which the tax authorities have detected the tax evasion themselves. As mentioned above, a voluntary disclosure usually has to contain all information necessary to assess taxes, and usually includes a revised tax return. Having this information prepared in a structured form likely lowers administrative costs for the tax authorities. However, it is also possible that most work arises when checking the accuracy of the disclosure. In that case, voluntary disclosures would not save administrative costs.

Only the tax authorities themselves can answer which of these arguments predominates in reality. Therefore, I have carried out a survey among all regional tax offices in Germany. I received answers from 12 of the 16 states. In eight cases, an agency at the level of the state answered, usually based on its own survey among the competent local tax authorities. From four other states, I directly received answers from competent local tax authorities, so that I have a total of 18 individual answers.

My first question asked whether a voluntary disclosure increased or decreased the work time necessary to assess taxes, compared to a situation where the evasion has already been detected (e.g. by receiving whistle-blower information). A strong majority $(\sim 60 \%)$ noted that administrative effort is significantly lower after a voluntary disclosure. When asked to quantify by how much the working time decreased, the answers ranged from $30 \%$ to $90 \%$, with two thirds citing a decrease in the necessary work time above $80 \%{ }^{11}$ Overall, a majority of respondents confirmed the argument made above that a voluntary disclosure strongly decreases the administrative effort necessary to assess previously evaded taxes.

A second question gauged the absolute volume of administrative costs, by asking about the hours of work necessary to assess taxes after a voluntary disclosure. The answers ranged from "minutes" to several months, with an average of five days. This range has to be expected, given that the voluntary disclosures concern very different cases: They range from individuals who forgot to file a foreign account in a single year, to others who have multiple offshore accounts with holdings in several funds, where

\footnotetext{
${ }^{11}$ About $16 \%$ of participants answered that the necessary work time increased, giving fact-checking efforts as the main reason. However, none of these respondents gave a numerical estimate by how much the required work time increased. The remainder stated that the work time does not change or did not answer, noting that the answer varies too much case by case.
} 
all realizations of capital gains in the last ten years have to be retraced. Interestingly, those competent local tax authorities who gave relatively high work time estimates also were more likely to answer that voluntary disclosure substantially lowers administrative costs. Possibly these local authorities deal predominantly with large cases, where the potential gains from voluntary disclosures are higher than for small cases.

All in all, the survey evidence confirms that for many competent tax authorities, voluntary disclosures implies administrative cost that are substantially (up to 90\%) lower than when assessing taxes based on whistle-blower information. In this situation the model predicts that government allows voluntary disclosures and fines them at a relatively low rate, as is the case in Germany (see Section 3.2).

\section{Empirical Analysis}

In the following, I empirically test some aspects of voluntary disclosure. The main test considers Proposition 1, i.e. whether voluntary disclosure increases tax evasion. In a second test, I analyze a shock to the detection probability to gauge the size of the tax revenues effects.

First, I study how the introduction of a voluntary disclosure program in the U.S. in 2009 affected tax evasion. In the model, this corresponds to comparing the case with voluntary disclosure with the one without it (see Figure 3). In Proposition 1 the model predicted that introducing voluntary disclosure increases tax evasion. To test this effect, I use data on offshore account balances, comparing the offshore deposits of U.S. residents with those from various control countries using a synthetic control method.

Moreover, the model predicts that voluntary disclosures take place only when the high detection probability occurs, and that the voluntary disclosures lead to increased net tax revenues. An event that came close to such an exogenous increase in the detection probability is the acquisition of whistle-blower data of Swiss bank accounts by German tax authorities in early 2010. Figure 1 on page 6 confirmed that this acquisition was indeed associated with a strong increase in the use of voluntary disclosures. Section 3.2 uses this development to estimate the additional revenue raised by voluntary disclosures. This estimation is no true test of Proposition 2, as the counterfactual revenue without the voluntary disclosure program is unknown. In contrast, it compares the situation in which nature has drawn $p_{L}$ with one in which nature has drawn $p_{H}$. 
It thus gives an estimate of the average size of voluntary disclosures, a helpful number when discussing the policy consequences of this analysis.

\subsection{United States: Voluntary Disclosure and Tax Evasion}

\subsubsection{Background}

The U.S. introduced a voluntary disclosure program in 2009. The IRS already experimented with voluntary disclosure programs in the first half of the twentieth century. However, since 1952, no formal policy regarding the civil penalties for intentional tax evaders has existed until 2009. ${ }^{12}$ In the criminal prosecution of tax evaders, individuals who came forward voluntarily have long been treated more favorably. Nevertheless, the 2009 initiative was the first large program to introduce a significantly more favorable civil tax penalty. ${ }^{13}$ Therefore, the introduction of the voluntary disclosure program significantly affected the expected penalties perceived by U.S. residents.

The 2009 program ran from mid-March till mid-October 2009 and was considered a success: About 15,000 taxpayers voluntarily disclosed prior tax evasion (U.S. Government Accountability Office, 2014). In February 2011, the IRS announced a follow-up program (the 2011 Offshore Voluntary Disclosure Initiative), which ended in mid-September 2011. Again, a large number of taxpayers (about 18,000) took advantage of this program. Ultimately, the IRS began an open-ended offshore voluntary disclosure program (OVDP) in January 2012. Table 2 provides an overview of some of the locations of foreign accounts declared in the 2009 program, showing that they referred to many different countries.

[Table 2 about here.]

\footnotetext{
${ }^{12}$ An exception was a three-month program in 2003 (the 2003 offshore voluntary compliance initiative), which was aimed mostly at taxpayers who used offshore payment cards. As only 1,321 taxpayers used the 2003 initiative, I will in the following focus on the program started in 2009. For more information on the history of voluntary disclosure in the U.S. see Madison (2001) and U.S. Government Accountability Office (2013).

${ }^{13}$ According to an example by the IRS, tax and penalty payments for a foreign account with $\$$ 1 million and 5\% yearly interest would accrue to $\$ 368,000$ after a voluntary disclosure in the 2009 program, compared to $\$ 2,306,000$ without the voluntary disclosure (IRS, 2009).
} 
All three initiatives had relatively similar requirements. ${ }^{14}$ They referred specifically to unreported income from undisclosed offshore accounts for years after 2003. Individual taxpayers disclosing income in the program have to pay the full amount of tax, plus interest, and a monetary penalty of up to $25 \%$ of unpaid taxes. Moreover, there is an additional penalty of 20\% (2009 program), 25\% (2011 initiative) or 27.5\% (2012 program) of the value of the assets in the foreign bank accounts. These penalties are significantly lower than the general punishments for tax evasion or failure to declare foreign accounts. ${ }^{15}$ Table 3 gives an overview of the taxes and penalties paid by participants in the 2009 OVDP.

[Table 3 about here.]

I use the introduction of the first program in 2009 to estimate how the existence of voluntary disclosure has affected tax evasion activities. While the 2009 program was only temporary, it marked a definite change in the IRS' policy towards tax evaders: for the first time since 1952, a broad and encompassing scheme for repentant tax evaders was put in place. While no follow-up program was originally announced, the IRS' formal acknowledgement that it treats tax evaders who come forward voluntarily in a more lenient way likely constitutes a significant shift in the perceived treatment of tax evaders. ${ }^{16}$ It is therefore suited to test Proposition 1 despite formally being a temporary program. ${ }^{17}$

\footnotetext{
${ }^{14}$ For details, see the IRS homepage at www.irs.gov/uac/2009-Offshore-Voluntary-DisclosureProgram, www.irs.gov/uac/2011-Offshore-Voluntary-Disclosure-Initiative and www.irs.gov/uac/2012Offshore-Voluntary-Disclosure-Program.

${ }^{15}$ Civil penalties for tax evasion are the greater of $\$ 100,000$ or $50 \%$ of the total balance of the foreign account. In addition, criminal penalties of up to $\$ 500,000$ or up to 10 years of imprisonment are possible for the failure to file a report of foreign bank and financial accounts (OECD, 2010a).

${ }^{16}$ In Question \& Answer section for the 2009 voluntary disclosure program, the IRS states that "taxpayers run a substantial risk that (...) the terms will be less beneficial to taxpayers" in the future (IRS, 2009). By noting that terms will be "less beneficial", the IRS implicitly indicated that there would still be a somewhat beneficial treatment of voluntary disclosures after the formal program ended.

${ }^{17}$ The only country that recently introduced voluntary disclosure into the general law was Switzerland in 2010. However, as a general shift in the policy towards tax evaders took place in Switzerland around that time, it is not possible to analyze the consequences that the introduction of voluntary disclosure had there.
} 


\subsubsection{Data and Descriptives}

By its nature, data on tax evasion is scarce. I therefore proxy for tax evasion using the deposits of U.S. residents in an aggregate of offshore banking centres. The Bank for International Settlements (BIS) provides this data on a quarterly basis. It collects the information necessary to compile this dataset from local banks in cooperation with the respective countries' central banks. The offshore banking centers in this aggregate are the Bahamas, Bahrain, Bermuda, Cayman Islands, Curaçao (from Q4 2010), Guernsey, Hong Kong, Isle of Man, Jersey, Macao, Netherlands Antilles (to Q3 2010), Panama, and Singapore. ${ }^{18}$

The BIS designates these countries as offshore financial centers. At the same time, the economic literature identifies all of these countries as tax havens (Hines and Rice, 1994). In the following analysis, I make the assumption that the combination of bank secrecy and low tax rates makes these offshore financial centers a potentially attractive location for tax evaders. Table 4 gives an overview of the amount of assets held in these offshore banking centres, and shows that these assets make up a significant fraction of the overall assets U.S. residents hold abroad.

\section{[Table 4 about here.]}

There are some potential issues with measuring tax evasion indirectly by foreign assets: First, it is not clear if these deposits really belong to individuals. Johannesen and Zucman (2014) show that households hold at least 50\% of the tax haven deposits. Second, it is possible that individuals do pay tax on this income. There is, however, little reasons except tax evasion for individuals to hold assets in the very small countries in the offshore banking aggregate. ${ }^{19}$

A further potential problem when studying the introduction of voluntary disclosure in the U.S. is the Foreign Account Tax Compliance Act (FATCA), which went into effect on March 18, 2010, about a year after the introduction of voluntary disclosure. It requires foreign financial institutions to report relevant information on their U.S.

\footnotetext{
${ }^{18}$ Unfortunately, data is only available for the aggregate of all offshore banking centers, not for individual offshore countries.

${ }^{19}$ Johannesen and Zucman (2014) also show that tax treaties signed by a tax haven significantly decrease deposits held in this haven, confirming that tax haven deposits are a reasonable proxy for evaded taxes. I will discuss later how the signing of tax treaties may impact the results.
} 
clients to the IRS. However, it applies only to transactions made after December 31, 2012. ${ }^{20}$ U.S. residents likely adjusted their portfolios sometime after FATCA was passed and before it went into effect. In this study, I thus focus on the two years after the introduction of voluntary disclosure, ending the observation period in the first quarter of 2011, well before FATCA went into effect.

\subsubsection{Research Design}

I use the synthetic control method, which Abadie et al. (2010) developed specifically to analyze the effectiveness of policy interventions at an aggregate level. ${ }^{21}$ This method extends the difference-in-differences framework to allow that the effects of unobserved variables on the outcome vary over time. It proceeds by creating a control region ("synthetic U.S.") from a weighted average of other countries without policy changes (the "donor pool"). The weights are chosen so that the synthetic U.S. are as similar as possible to the U.S. Specifically, denoting the vector of preintervention variables for the treated country by $X_{1}$, and a matrix with characteristics of the potential control countries by $X_{0}$, the synthetic control method chooses the weights $W$ used in forming the synthetic control to minimize $\sqrt{\left(X_{1}-X_{0} W\right)^{\prime} V\left(X_{1}-X_{0} W\right)}$, where $V$ is a positive semidefinite matrix chosen to minimize the mean square prediction error over the pretreatment period. An important advantage of this method is that the data choose the control group, instead of the researcher.

The BIS has made available the data on deposits in offshore banking centers of counterparties from most OECD countries (Austria, Belgium, Canada, Czech Republic, Denmark, Finland, France, Germany, Hungary, Ireland, Israel, Luxembourg, Mexico, Netherlands, Norway, Poland, Slovak Republic, Slovenia, Spain, Sweden, Switzerland, Turkey, United Kingdom and the United States). I discard from the donor pool the countries that also significantly changed their voluntary disclosure program in the time period (France, Israel, Mexico, Netherlands, Switzerland, Turkey and the United Kingdom). I also drop Germany due to the special circumstances described in Section 3.2, and Norway due to a large field experiment that was carried out on the full population of offshore tax evaders (Bott et al., 2014). As almost all counterparty countries signed tax treaties with one or some of the countries in the offshore banking aggregate, I

\footnotetext{
${ }^{20}$ The implementation of FATCA usually requires intergovernmental agreements. The U.S. signed such agreements with the countries in the offshore banking aggregate only in late 2013 and early 2014.

${ }^{21}$ For other applications of this method see e.g. Kleven et al. (2013) or Hinrichs (2012).
} 
cannot drop these counterparties. No country, however, has signed tax treaties with all offshore banking centers in the sample period. The data set is on a quarterly basis, starting in the first quarter of 2006, so that data on twelve pre-intervention quarters is available.

The outcome variable of interest, Liab, are the deposits in offshore banking centers held by residents of various countries ("counterparty countries"). I use the BIS variable "All instruments", which includes deposits, holdings of securities, and other liabilities of the offshore banks towards residents in the counterparty countries. I scale the deposits by the GDP of the counterparty country.

I then construct the synthetic United States to match the real United States as closely as possible. I do so in two ways: First, I construct this synthetic control based only on prior values of Liab, using the lag of the last quarter before the introduction of voluntary disclosure (Q4 2008), and then every other quarter going back to Q2 2006. Second, I match on two additional variables: per capita GDP to control for differences in available income, and the capital tax rate as provided in the OECD tax database to measure different incentives for evading taxes on capital income. In the following section I focus on the second case. Appendix 2 presents results when matching only on prior values of Liab.

\subsubsection{Results}

Using the approach described above and matching on per capita GDP, the capital tax rate and prior values of Liab, I find that a combination of Canada (77.1\%), Austria (10.0\%), Luxembourg (6.7\%) and Sweden (6.2\%) matches the United States best. All other countries obtain a zero weight in the construction of the synthetic United States.

During the period studied, there were only a few tax treaties between these countries and offshore banking centers: between Canada and the Netherlands Antilles, signed on August 29, 2009, between Sweden and Guernsey and Jersey, signed on October 28, 2008, and Sweden and Bermuda and the Cayman Islands, signed in April 2009. ${ }^{22}$ These tax treaties affect only a few of the countries included in the offshore banking aggregate. Moreover, if tax evaders shifted their deposits from one of these countries to other tax havens in response to the treaties (as suggested by Johannesen and Zucman, 2014), they likely shifted them to another offshore banking center.

\footnotetext{
${ }^{22}$ Based on tax treaty information from Johannesen and Zucman (2014).
} 
Figure 4: Trends in Liab: United States vs. synthetic United States

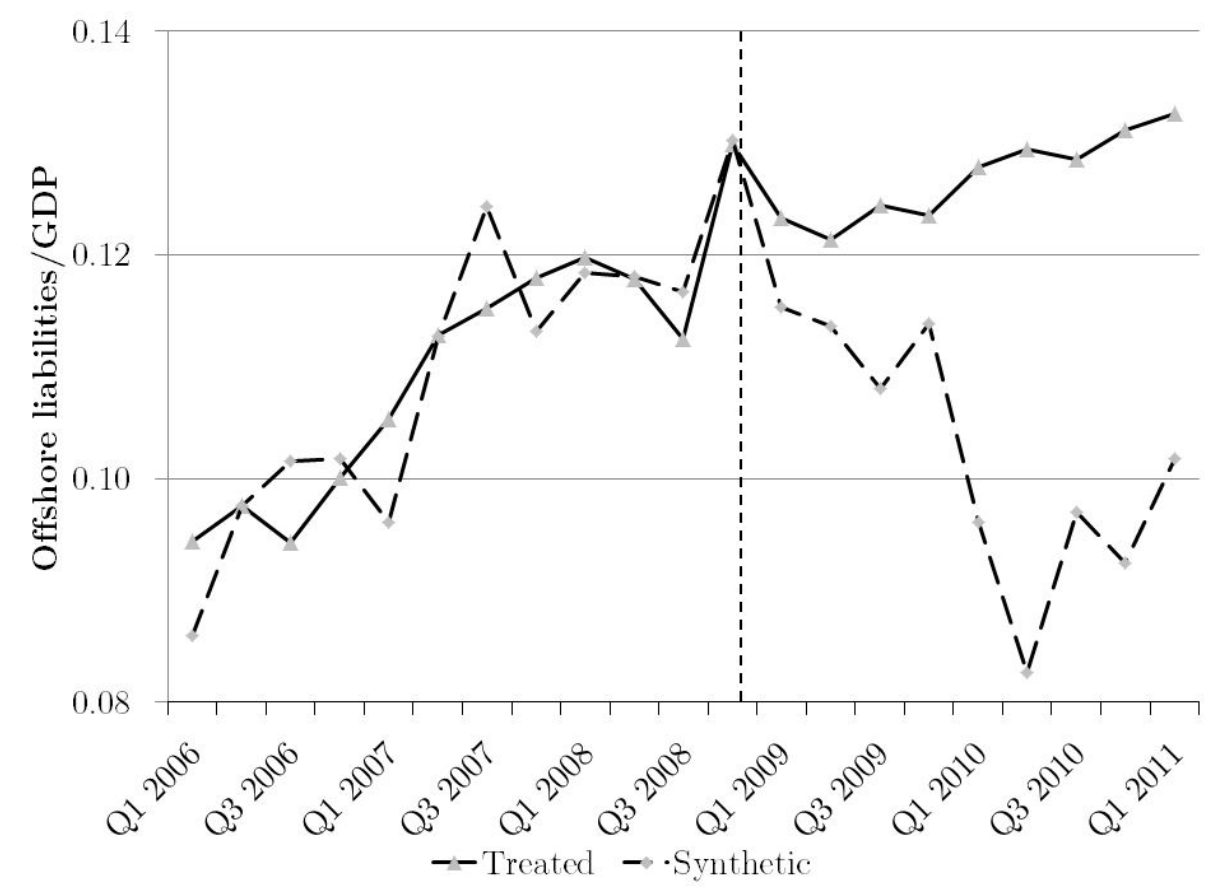

Figure 4 shows how the offshore deposits of residents of the United States (solid line) and its synthetic counterpart (dashed line) evolved during the period Q1 2006 to Q1 2011. Before the voluntary disclosure initiative in 2009, the deposits of the synthetic United States follow those of the real United States reasonably closely. Thus, the synthetic control should be a sensible approximation of how the United States would have behaved if they had not introduced voluntary disclosure.

After the introduction of voluntary disclosure in the first quarter of 2009, the offshore deposits of the United States clearly diverge from their synthetic counterpart. Relative to the synthetic control, the deposits of U.S. residents rise significantly. ${ }^{23}$ This development is in line with the prediction from the model that the existence of a voluntary disclosure program, and thus the ability to come clean at a relatively low cost when circumstances warrant it, increases tax evasion.

In Figure 4, there is a noticeable decrease in the offshore deposits of the synthetic

${ }^{23}$ In absolute values, the offshore deposits of the U.S. fall, and those of the synthetic control fall even more. This decrease is likely due to the growing public and political pressure against tax havens in early 2009, which culminated in the announcement of the G20 at its London summit in April 2009 that it would crack down on tax havens (for details see Johannesen and Zucman, 2014). 
control in early 2010. This fall is likely due to the Euro crisis, as the synthetic control partially consists of Euro member countries. It is thus not clear how well the synthetic control replicates the U.S. in 2010. Nevertheless, also when considering only 2009, offshore liabilities of the U.S. are considerably higher than those of their synthetic counterpart.

Could something other than the voluntary disclosure program be driving these results? One possible alternative explanation is the election of Barack Obama as president of the United States. The election of a Democrat may have raised fears of higher capital taxes, which may in turn have increased the incentive to hide money offshore. However, while Barack Obama was inaugurated in January 2009, he was already elected in September 2008, one quarter before the U.S. starts to diverge from its synthetic counterpart. Moreover, recent literature shows that a higher marginal tax rate has at most a very small effect on tax evasion (Kleven et al., 2011). Therefore, it is reasonable to believe that the introduction of voluntary disclosure was an important determinant of the increased tax evasion in Figure 4.

To evaluate the significance of the visual result from Figure 4, one has to consider if chance alone could be driving it. To evaluate this, I carry out placebo tests where I randomly select a country instead of the United States as the treated country. If the placebo studies show that the gap estimated for the U.S. is unusually large relative to the gaps of the countries that did not introduce voluntary disclosure, the present analysis provides significant evidence of an effect of voluntary disclosure.

Figure 5 shows the results of this placebo test. It applies the synthetic control method to every country in the donor pool. Each line in Figure 5 represents the gap between Liab of the treated and the synthetic control for one country. The gray lines show the gap for countries in the donor pool, and the black line denotes the gap estimated for the United States. ${ }^{24}$ The placebo test shows that the high values of Liab in 2009 to 2011 are unlikely to arise by chance, confirming the theoretical result that the introduction of voluntary disclosure leads to more tax evasion.

To test the robustness of these results, I repeat the analysis matching only on prior values of Liab, as Abadie et al. (2010) originally suggested. In this case, the synthetic

\footnotetext{
${ }^{24}$ As in Abadie et al. (2010), I drop countries that have a preintervention mean squared prediction error at least double that of the United States. This step is necessary as convex combinations of other countries cannot reproduce all countries sufficiently well, leading to some mean squared prediction errors that are many times larger than that of the United States.
} 
Figure 5: Placebo test

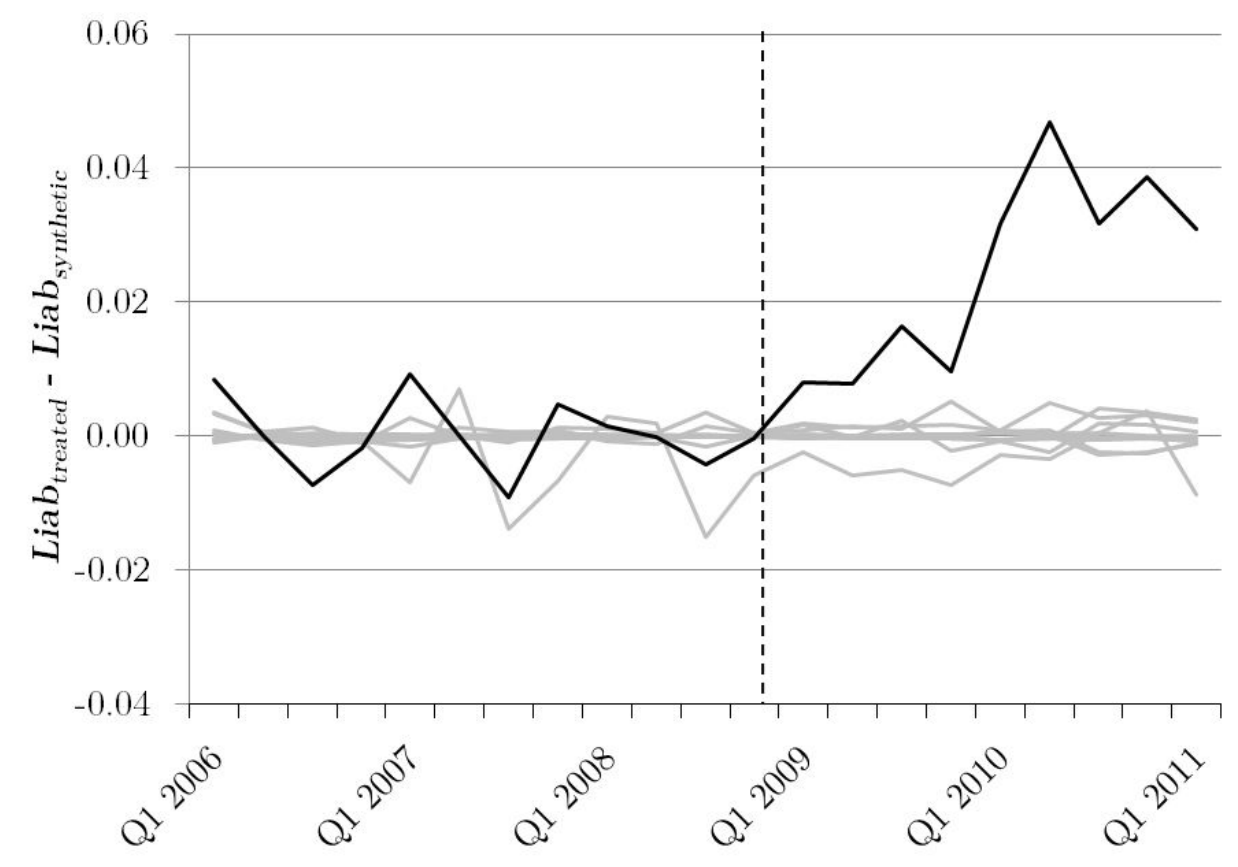

United States are a combination of Denmark (79.5\%), Sweden (8.2\%), Luxembourg (7.2\%) and Austria (5.1\%). Despite this different control group, the results (reported in Appendix 2 in more detail) are very similar to the analysis with controls presented above. The result of increased tax evasion is thus robust to different choices of the synthetic control group.

\subsection{Germany: Voluntary disclosure and tax revenues}

\subsubsection{Background}

Germany has a long-established voluntary disclosure program in its general tax law. It treats a voluntary disclosure as a means to return to "tax honesty" and does not punish tax evasion if the taxpayer voluntarily discloses the tax evasion before the tax authorities start an investigation. For a successful voluntary disclosure, an individual has to report all taxes evaded in the last ten years. He then has to repay the taxes evaded in this ten-year period, plus a $6 \%$ interest payment per year. There is no fine (beyond the heightened interest rate) after a voluntary disclosure. ${ }^{25}$

${ }^{25}$ For details (in German) see Wittig (2014). 
The possibility of a penalty-free voluntary disclosure has led to public discussion after some German federal states bought data sets provided by informants from tax haven banks. This significantly increased the (perceived) detection probabilities for tax evasion. The German state of Northrhine-Westphalia bought the first large dataset on February 26th, 2010. ${ }^{26}$ It contained information on the names and credit balances of German-owned accounts in Switzerland. The state of Northrhine-Westphalia, cofinanced by the federal government of Germany, paid €2.5 million to an unknown informant. Since then, Germany has bought several other additional CDs with data on accounts in Switzerland and Luxembourg. The data have been shared freely among the German federal states, which are the jurisdictions in charge of all tax collections, including federal income taxes.

\subsubsection{Research Design}

In the theoretical setting presented in Section 2, a higher detection probability induces some individuals who chose to evade taxes earlier to voluntarily disclose. This empirical test provides some first evidence to quantify the additional tax revenue these voluntary disclosures bring in.

I use that German statistics separate income tax revenues into different categories. ${ }^{27}$ One such category is the veranlagte Einkommensteuer, self-reported income tax, which summarizes all revenue collected from self-reported income, such as entrepreneurial income, interest income received on foreign bank accounts, and revenue raised after a voluntary disclosure. In contrast, interest and dividend income earned within Germany, or on foreign assets held in a deposit at a German bank, are subject to Abgeltungsteuer, capital income withholding tax. Banks deduct this tax automatically, so that there is no scope for tax evasion. In the following I will employ a difference-in-difference (DiD) design, testing how the increase in the detection probability after the acquisition of the first whistle-blower data set in February 2010 changed the self-reported income tax

\footnotetext{
${ }^{26}$ Already in 2006, Germany acquired a dataset containing information on around 800 Luxembourgian bank accounts. This dataset was smaller than those bought after 2010, which sometimes contained several ten thousand accounts. For details, see FAZ (2011).

${ }^{27}$ The data in this section is from the GENESIS data base provided by the German Federal Statistical Office.
} 
revenue relative to the capital income withholding tax revenue. ${ }^{28}$

The validity of the DiD analysis rests on the assumption of common trends before the intervention. This precondition implies that without the treatment, the dependent variable of treated and control groups would move in the same direction. Figure 6 shows yearly tax revenues in both tax categories to provide some evidence that this assumption holds. Revenues from self-reported income tax, and from capital income withholding tax, both increase from 2006-2008, then fall in 2009. These movements are broadly in line with the overall economic development in Germany in these years. In 2010, after the acquisition of the whistle-blower data, the revenues for the two tax collection methods diverge: while withholding tax revenues continue to decline, revenues from self-reported income tax revenues increase, implying that the additional revenues from voluntary disclosures overcompensate the negative trend in tax revenues.

\subsubsection{Results}

Table 5 reports results from this DiD test. In Col. (1), it shows that a higher detection probability in Germany led to an increase in tax revenues of about $€ 468$ million over the next year (Col. 1). Therefore, voluntary disclosures in Germany contribute significantly to tax revenues.

\section{[Table 5 about here.]}

Columns (2) to (4) report several robustness tests. First, Col. (2) repeats the test using quarterly data, adding quarter fixed effects. Consistent with the results using yearly data, I find that the voluntary disclosures lead to a tax revenue increase of $€ 117$ million per quarter. Second, I use other tax revenues as control groups to ascertain that no unobserved change in the capital income withholding tax revenue drives the result. Specifically, I use revenues from payroll tax (Lohnsteuer) in Col. (3) and from other

\footnotetext{
${ }^{28}$ In a more dynamic setting a higher detection probability would also lead to less tax evasion in later periods. This change would primarily increase the capital income withholding tax revenue, as most people invest via a domestic bank when not evading taxes. German banks withhold taxes on capital income also when the capital is invested in foreign assets. Simply declaring wealth held abroad on which taxes were evaded earlier is a highly risky strategy, as this attracts attention from auditors, and most high-income individuals in Germany are audited. Thus, as lower tax evasion mostly affects capital income withholding tax revenue, the revenue estimates from the $\mathrm{DiD}$ test should reflect only the direct revenue effect of voluntary disclosures.
} 
Figure 6: Revenues of veranlagte Einkommensteuer, self-reported income tax, and Abgeltungsteuer, capital income withholding tax, 2006-2010.

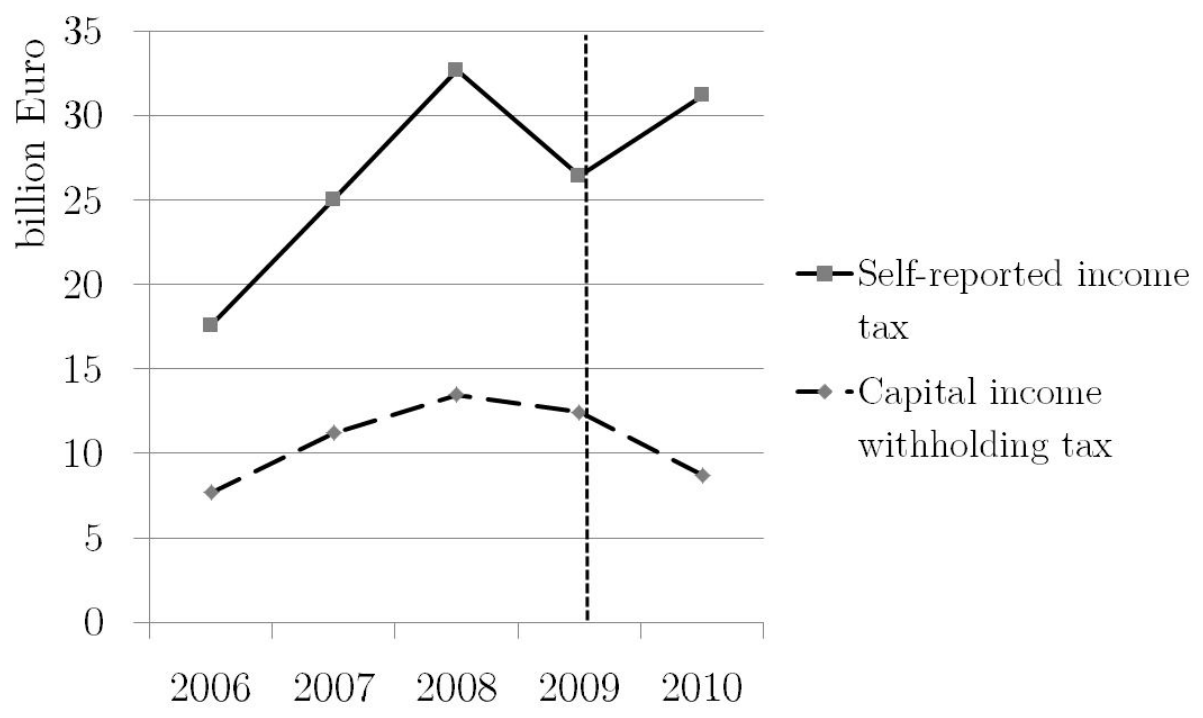

withheld income taxes (nicht veranlagte Steuern vom Ertrag), which mostly consists of capital income tax paid by firms, in Col. (4). In both cases I get similar results, albeit not significant when using other withheld income taxes as the control.

Lastly, I consider the additional revenue a voluntary disclosure brings in on average. All German federal states have answered queries about the number of voluntary disclosures, yielding a total of 28,329 voluntary disclosures in 2010 (see Figure 1). Comparing this number to the average for the years 2006 to 2009, the increased detection probability in Germany in 2010 caused about 18,100 additional voluntary disclosures. Based on these numbers and the main results from Col. (1), the average additional revenues per voluntary disclosure are $€ 26,000$. Considering that taxes for the last ten years have to be paid after a voluntary disclosure, this number is relatively modest: At the standard tax rate of $25 \%$, this implies undeclared capital income around $€ 100,000$ over this ten year period.

\section{Conclusion}

This paper provides some first results on the effects of voluntary disclosure of tax evasion, a topic that has so far not been studied in the economics literature. The the- 
oretical model has pointed out that the existence of a voluntary disclosure mechanism increases tax evasion. The empirical analysis considering the introduction of voluntary disclosure in the U.S. has confirmed this effect. Nevertheless, for a revenue-maximising government, a voluntary disclosure program can be sensible as it provides a way to collect revenues without incurring high administrative costs for prosecuting tax evaders. Evidence from Germany has shown that these administrative costs are significant, and also provided some estimates for the revenues that voluntary disclosures can bring in.

The topic of voluntary disclosures is especially relevant today, as the detection probabilities for tax evaders have gone up in many countries (e.g. due to whistle-blowers or to better information exchange with tax havens). Therefore, voluntary disclosures have recently played a larger role. In this environment, a voluntary disclosure program is attractive for the government, as it can increase its revenues without overburdening its tax administration. When governments expect further increases in the detection probability, the model predicts they should increase the fine that applies after a voluntary disclosure.

As this paper is the first to study voluntary disclosures, it has been able to shed light on only some of its aspects. A possible extension might consider a situation in which the tax authority has a fixed budget (at least in the short term) and has to allocate its money between catching evaders and prosecuting caught evaders; i.e. it has to trade off a higher detection probability versus the administrative costs of assessing the tax returns of former evaders. A voluntary disclosure program clearly alleviates this tradeoff.

Further arguments concerning voluntary disclosure programs lie outside the revenue-maximization framework provided in this paper. On moral grounds, voluntary disclosure may be desirable as it offers a good way to come clean for taxpayers who have made unintentional errors when filing their tax returns, or inherited offshore accounts. In contrast, opponents of voluntary disclosure question the fairness of allowing tax evaders to come clean with a very low or even no punishment. In any case, the topic of voluntary disclosures of tax evasion clearly provides interesting further research questions and scope for discussion. 


\section{References}

Abadie, A., Diamond, A., Hainmueller, J., 2010. Synthetic control methods for comparative case studies: Estimating the effect of California's tobacco control program. Journal of the American Statistical Association 105, 493-505.

Agarwal, S., Marwell, N., McGranahan, L., 2013. Consumption responses to temporary tax incentives: Evidence from state sales holidays. Availabe at SSRN, papers.ssrn. com/sol3/papers.cfm?abstract_id=2178753.

Allingham, M. G., Sandmo, A., 1972. Income tax evasion: A theoretical analysis. Journal of Public Economics 1, 323-338.

Alm, J., 2012. Measuring, explaining, and controlling tax evasion: Lessons from theory, experiments, and field studies. International Tax Public Finance 19, 54-77.

Alm, J., Beck, W., 1990. Tax amnesties and tax revenues. Public Finance Quarterly 18, 433-453.

Alm, J., Beck, W., 1993. Tax amnesties and compliance in the long run: A time series analysis. National Tax Journal 46, 53-60.

Alm, J., McClelland, G. H., Schulze, W. D., 1992. Why do people pay taxes? Journal of Public Economics 48, 21-38.

Andreoni, J., 1991. The desirability of a permanent tax amnesty. Journal of Public Economics 45, 143-159.

Besley, T., Meads, N., Surico, P., 2014. The incidence of transaction taxes: Evidence from a stamp duty holiday. Journal of Public Economics, doi: 10.1016/j.jpubeco.2014.07.005.

Bott, K., Cappelen, A., Sørensen, E. Ø., Tungodden, B., 2014. You've got mail: A randomised field experiment on tax evasion. NHH Norwegian School of Economics.

Cameron, C. A., Gelbach, J. B., Miller, D. L., 2008. Bootstrap-based improvements for inference with clustered errors. Review of Economics and Statistics 90, 414-427.

Cole, A. J., 2009. The fiscal impact of sales tax holidays. University of Michigan. 
Dhami, S., Al-Nowaihi, A., 2010. Optimal taxation in the presence of tax evasion: Expected utility versus prospect theory. Journal of Economic Behavior \& Organization $75,313-337$.

FAZ, 2011. Razzia gegen Steuersünder ist angelaufen. Frankfurter Allgemeine Zeitung, 16. October 2011, www.faz.net/-gqe-6udzt.

Feess, E., Heesen, E., 2002. Self-reporting and ex post asymmetric information. Journal of Economics 77, 141-153.

Feess, E., Walzl, M., 2005. Optimal self-reporting schemes with multiple stages and option values. International Tax and Public Finance 12, 265-279.

Gravelle, J. G., 2009. Tax havens: International tax avoidance and evasion. National Tax Journal 62, 727-753.

Hines, J. R., Rice, E. M., 1994. Fiscal paradise: Foreign tax havens and American business. The Quarterly Journal of Economics 109, 149-82.

Hinrichs, P., 2012. The effects of affirmative action bans on college enrollment, educational attainment, and the demographic composition of universities. Review of Economics and Statistics 94, 712-722.

IRS, 2009. Voluntary Disclosure: Questions and Answers. http://www.irs.gov/uac/ Voluntary-Disclosure:-Questions-and-Answers.

Johannesen, N., Zucman, G., 2014. The end of bank secrecy? An evaluation of the G20 tax haven crackdown. American Economic Journal: Economic Policy 6, 65-91.

Kaplow, L., Shavell, S., 1994. Optimal law enforcement with self-reporting of behavior. Journal of Political Economy 102, 583-606.

King, S., Sheffrin, S., 2002. Tax evasion and equity theory: An investigative approach. International Tax and Public Finance 9, 505-521.

Kleven, H. J., Knudsen, M. B., Kreiner, C. T., Pedersen, S., Saez, E., 2011. Unwilling or unable to cheat? Evidence from a tax audit experiment in Denmark. Econometrica $79,651-692$. 
Kleven, H. J., Landais, C., Saez, E., 2013. Taxation and international migration of superstars: Evidence from the European football market. American Economic Review 103, 1892-1924.

Kolm, S.-C., 1973. A note on optimum tax evasion. Journal of Public Economics 2, $265-270$.

Madison, A. D., 2001. An analysis of the IRS's voluntary disclosure policy. Tax Lawyer $54,729-752$.

Malik, A. S., Schwab, R. M., 1991. The economics of tax amnesties. Journal of Public Economics 46, 29-49.

OECD, 2010a. SMEs, Entrepreneurship and Innovation. OECD Publishing.

OECD, 2010b. Offshore Voluntary Disclosure: Comparative Analysis, Guidance and Policy Advice. OECD Publishing.

Pfisterer, V., 2013. Walking a fine line - a contextual perspective on the purchase of "stolen" banking data by German authorities. German Law Journal 14, 926-948.

Sandmo, A., 2005. The theory of tax evasion: A retrospective view. National Tax Journal 58, 643-663.

Slemrod, J., 2007. Cheating ourselves: The economics of tax evasion. Journal of Economic Perspectives 21, 25-48.

Stella, P., 1991. An economic analysis of tax amnesties. Journal of Public Economics 46, 383-400.

U.S. Government Accountability Office, 2013. Offshore Tax Evasion: IRS Has Collected Billions of Dollars, but May be Missing Continued Evasion. GAO-13-318.

U.S. Government Accountability Office, 2014. IRS's Offshore Voluntary Dislosure Program: 2009 Participation by State and Location of Foreign Bank Accounts. GAO14-265R.

Wittig, P., 2014. Die Selbstanzeige bei Steuerstraftaten. JURA - Juristische Ausbildung 36 , p. $567-579$.

Yitzhaki, S., 1974. A note on income tax evasion: A theoretical analysis. Journal of Public Economics 3, 201-202. 
Zucman, G., 2013. The missing wealth of nations: Are Europe and the U.S. net debtors or net creditors? Quarterly Journal of Economics 128, 1321-1364. 


\section{Appendix 1: Model with Risk Averse Individuals}

This appendix considers the implications of risk averse individuals in the model described in Section 2. Assume that individuals are homogenous (i.e. that $\alpha_{i}=0$ for all individuals) and maximize a well-behaved utility function $U(\cdot)$, with $U^{\prime}>0$ and $U^{\prime \prime}<0$. For simplicity, assume that there is no compliance cost when preparing the voluntary disclosure. As the focus of this extension is on the risk averse individual's decision, I do not analyze the behavior of the government here, and instead assume that the fine after a voluntary disclosure is zero $(f=1)$, as is the case in several countries (see Table 1).

Each individual receives an exogenous income $y$, but can choose to declare $x \leq y$ on his tax return. The utility if evasion is detected is $U^{F}=U[y-t x-F t(y-x)]$, and the corresponding utility if evasion is not detected is $U^{0}=U[y-t x]$. If evasion is voluntarily disclosed, the utility is $U^{v d}=U[y-t y]$. Following Allingham and Sandmo (1972), I assume that parameters are such that tax evasion is worthwhile ex-ante, i.e. that $\bar{p} F=\left[(1-q) p_{L}+q p_{H}\right] F<1$; and that $p_{H} F>1$, which implies that tax evasion is no longer worthwhile when the high detection probability occurs.

First, consider again the benchmark case without voluntary disclosure. In this benchmark model, which I denote by a hat on all decision variables, the individuals' expected utility is given by

$$
\widehat{E U}=q\left[p_{H} \widehat{U^{F}}+\left(1-p_{H}\right) \widehat{U^{0}}\right]+(1-q)\left[p_{L} \widehat{U^{F}}+\left(1-p_{L}\right) \widehat{U^{0}}\right]
$$

The first order condition that implicitly determines the individual's choice of $\hat{x}^{*}$ is

$$
\bar{p}{\widehat{U^{F}}}^{\prime}(F-1)-(1-\bar{p}){\widehat{U^{0}}}^{\prime}=0 .
$$

The optimal choice of the declared income, $\hat{x}^{*}$, trades off the probability of being caught and fined against the expected tax saving.

Expected tax revenue net of administrative costs in this benchmark case without voluntary disclosure, expressed per individual, is

$$
\widehat{T}=t \hat{x}+\bar{p} F t(y-\hat{x})-\bar{p} c^{a} .
$$

Next, consider how these outcomes change when voluntary disclosure is possible. As in the main model, individuals will only exercise the option to voluntarily disclose the tax evasion they rationally decided to commit earlier if nature draws $p_{H}$. 
Expected utility if voluntary disclosure is possible is

$$
E U=q U^{v d}+(1-q)\left[p_{L} U^{F}+\left(1-p_{L}\right) U^{0}\right] .
$$

The first term describes utility when the individual chooses to voluntarily disclose, and the second and third term depict the outcome when the low detection probability occurs and the individual either pays the fine (2nd summand) or successfully evades taxes (3rd summand).

Tax payers declare the income $x^{*}$ that maximizes Eq. (A.4). The corresponding first order condition is (after simplifying)

$$
p_{L} U^{F^{\prime}}(F-1)-\left(1-p_{L}\right) U^{0^{\prime}}=0 .
$$

Due to the voluntary disclosure possibility, only the outcomes in the state of the world with the low detection probability matter for the tax evasion decision. If the high detection probability occurs, the individual voluntary reports himself and pay the full tax liability.

Expected tax revenues per individual when voluntary disclosure is possible are

$$
T=q t y+(1-q)\left[t x+p_{L} F t(y-x)-p_{L} c^{a}\right] .
$$

If nature draws the high detection probability (which occurs with probability $q$ ), tax revenue is $t y$, as all individuals voluntarily disclose. Taxes are only evaded when the detection probability is low. Then, tax revenues are an average of successful evasion and full taxation plus fines, minus administrative costs.

Now consider how the option of voluntary disclosure affects tax evasion, i.e. $x^{*}$. Comparing the first oder conditions (A.2) and (A.5) gives

$$
\bar{p} \widehat{U}^{\prime}(F-1)-(1-\bar{p}) \widehat{U}^{\prime}=p_{L}(F-1) U^{F^{\prime}}-\left(1-p_{L}\right) U^{0^{\prime}},
$$

Note that $\bar{p}>p_{L}$ and correspondingly $1-\bar{p}<1-p_{L}$. Thus, for the equality in Eq. (A.7) to be fulfilled, it has to hold that ${\widehat{U^{F}}}^{\prime}<U^{F^{\prime}}$ and ${\widehat{U^{0}}}^{\prime}>U^{0^{\prime}}$, as $U^{0}$ and $U^{F}$ move into opposite directions when $x$ changes. Due to the concavity of the utility function, this implies that $\hat{x}^{*}>x^{*}$, i.e. that more tax is evaded (lower $x$ ) when voluntary disclosure is possible. This result is analogous to Proposition 1 from the main model.

More tax evasion could imply that a voluntary disclosure mechanism decreases tax revenues. However, voluntary disclosure could also increase expected tax revenues, as 
some individuals voluntary disclose whose tax evasion would not have been detected otherwise. These effects can be seen by comparing Eqs. (A.3) and (A.6):

$$
T-\hat{T}=-(1-q)\left(1-p_{L} F\right) t(\hat{x}-x)-q t\left(p_{H} F-1\right)(y-\hat{x})+q p_{H} c^{a} .
$$

The first summand shows that if voluntary disclosure is possible, individuals evade more taxes, which lowers tax revenues in the state of the world with the low detection probability. The second summand reflect the effects if the state of the world with the high detection probability occurs. If there are no administrative costs associated with assessing taxes of evaders who have not disclosed (i.e. $c^{a}=0$ ), then Eq. (A.8) is clearly negative; again showing that without administrative cost savings, there is no rationale for a voluntary disclosure program for a revenue-maximizing governments even when individuals are risk averse.

\section{Appendix 2: Alternative matching for U.S. Empirical Test}

This appendix repeats the analysis in Section 3.1, but matches only on lagged values of Liab to create the synthetic control. Then, a combination of Denmark (79.5\%), Sweden (8.2\%), Luxembourg (7.2\%) and Austria (5.1\%) match the United States best.

Figure A.1 shows how the offshore deposits of residents of the United States (solid line) and its synthetic counterpart (dashed line) evolved during the period Q1 2006 to Q1 2010. Again, offshore deposits of U.S. residents increase strongly after the voluntary disclosure program is introduced in 2009.

The placebo test that assigns the intervention to all donor countries in the sample confirms that this increase is unlikely to arise by change (Figure A.2). Again, the gray lines show the gap for countries in the donor pool, and the the black line denotes the gap estimated for the United States. 
Figure A.1: Trends in Liab: United States vs. synthetic United States

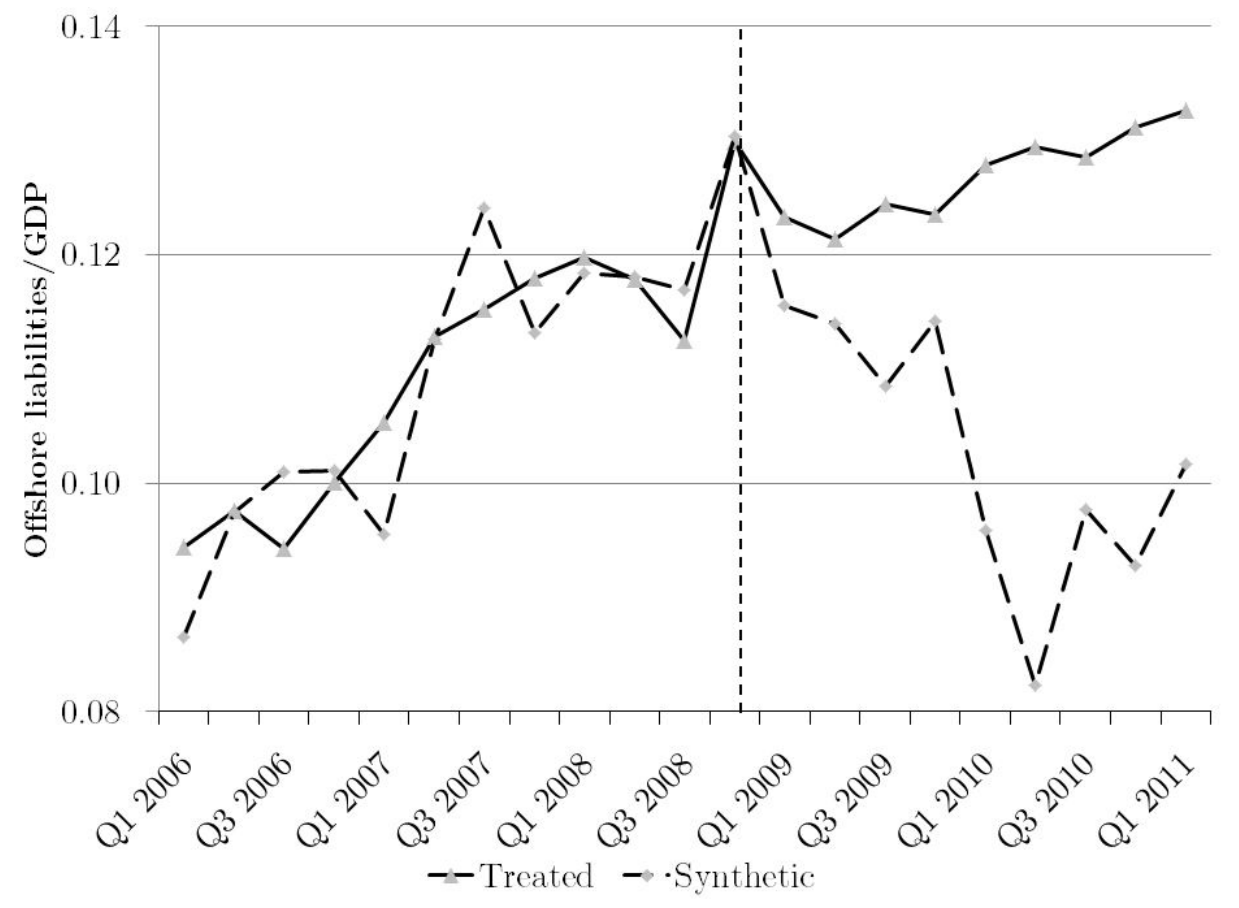

Figure A.2: Placebo test

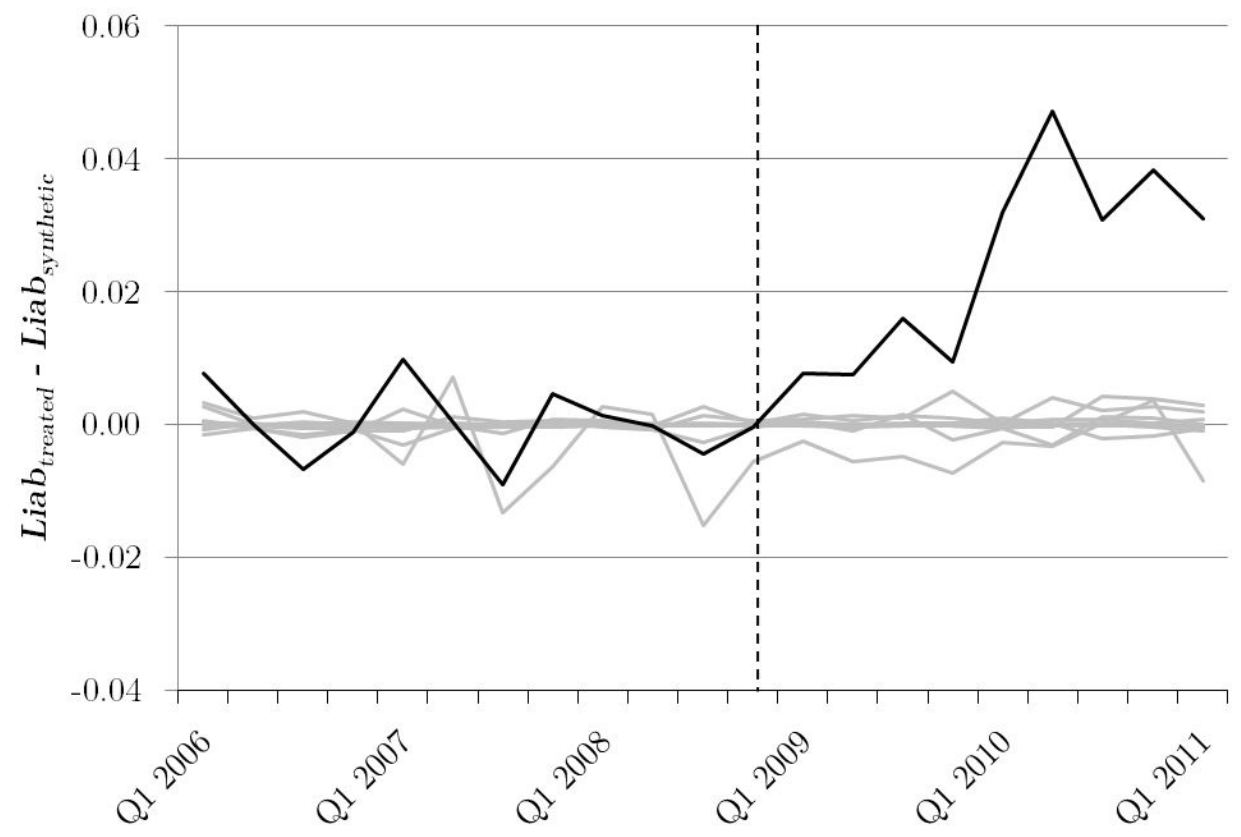




\section{Tables}

Table 1: Voluntary Disclosure in OECD Countries

\begin{tabular}{|c|c|c|c|c|c|}
\hline \multirow[t]{2}{*}{ Country } & \multirow[t]{2}{*}{ Legal Basis } & \multicolumn{2}{|c|}{ Tax \& Interest } & \multicolumn{2}{|c|}{ Penalty } \\
\hline & & $\operatorname{Tax}$ & Interest & Monetary & Imprisonment \\
\hline Australia & General law & Full amount & Varies & Varies & Possible \\
\hline Austria & General law & Full amount & $2.38 \%$ & No & No \\
\hline Belgium & General law & Full amount & $7.00 \%$ & $0-10 \%$ of $\operatorname{tax}$ & No \\
\hline Canada & General law & Full amount & Yes & No & No \\
\hline Chile & General law & Full amount & $1.50 \%$ & $10-300 \%$ of tax & $\leq 15$ years \\
\hline Czech Rep. & General law & Full amount & Ca. $15 \%$ & No & $\bar{N}_{0}$ \\
\hline Denmark & General law & Full amount & Varies & $50 \%$ of tax & Possible \\
\hline Estonia & General law & Full amount & $0.06 \% /$ day & $\leq 18,000 \mathrm{EEK}$ & Possible \\
\hline Finland & General law & Full amount & Yes & $30 \%$ of tax & $\leq 4$ years \\
\hline France & $\begin{array}{l}\text { Special program } \\
(2009,2013-14)\end{array}$ & Full amount & $0.4 \% /$ month & Varies & No \\
\hline Germany & General law & Full amount & $6.00 \%$ & No & No \\
\hline Greece & Special program & $\begin{array}{l}5 \% \text { to } 8 \% \text { of } \\
\text { total capital }\end{array}$ & & No & No \\
\hline Hungary & General law & Full amount & $\begin{array}{l}1.5-1.75 \mathrm{x} \\
\text { std. rate }\end{array}$ & $\begin{array}{l}\text { Only height- } \\
\text { ened interest }\end{array}$ & No \\
\hline Iceland & None & - & - & - & - \\
\hline Ireland & General law & Full amount & Varies & $3-10 \%$ of tax & No \\
\hline Israel & $\begin{array}{l}\text { Special program } \\
(2011-2012)\end{array}$ & Full amount & No & No & No \\
\hline Italy & $\begin{array}{l}\text { General law } \\
\text { Special program } \\
\text { in } 2008\end{array}$ & $\begin{array}{l}\text { Full amount } \\
5 \% \text { of assets }\end{array}$ & Varies & $\begin{array}{l}\text { Reduced } \\
\text { No penalty }\end{array}$ & No \\
\hline Japan & General law & Full amount & $4-14.6 \%$ & Varies & $\leq 10$ years \\
\hline Korea & General law & Full amount & $0.03 \% /$ day & Reduced & Varies \\
\hline Luxembourg & General law & Full amount & $0.6 \% /$ month & $\leq 10 \%$ of $\operatorname{tax}$ & No \\
\hline Mexico & $\begin{array}{l}\text { General law } \\
\text { Special program } \\
\text { in } 2009\end{array}$ & Full amount & $\begin{array}{l}\text { Yes } \\
4-7 \%\end{array}$ & $\begin{array}{l}\text { No } \\
\text { No }\end{array}$ & $\begin{array}{l}\text { Rarely } \\
\text { No }\end{array}$ \\
\hline Netherlands & $\begin{array}{l}\text { General law } \\
\text { Special program } \\
\text { in } 2009,2013\end{array}$ & $\begin{array}{l}\text { Full amount } \\
\text { Same as gen- } \\
\text { eral law }\end{array}$ & Varies & $\begin{array}{l}\leq 300 \% \text { of tax } \\
\text { No penalties }\end{array}$ & No \\
\hline $\begin{array}{l}\text { New } \\
\text { Zealand }\end{array}$ & General law & Full amount & Varies & Reduced & No \\
\hline Norway & General law & Full amount & Yes & No & No \\
\hline Poland & General law & Full amount & $\begin{array}{l}75 \% \text { of regu- } \\
\text { lar rate }\end{array}$ & No & No \\
\hline Portugal & General law & Full amount & $4.08 \%$ & Reduced & No \\
\hline & $\begin{array}{l}\text { Special program } \\
\text { in } 2009\end{array}$ & $\begin{array}{l}5 \% \text { of discl. } \\
\text { assets }\end{array}$ & None & No & No \\
\hline Slovak Rep. & General law & Full amount & Yes & No & No \\
\hline
\end{tabular}




\begin{tabular}{|c|c|c|c|c|c|}
\hline Slovenia & General law & Full amount & Increased & No & Possible \\
\hline Spain & General law & Full amount & Yes & $5-20 \%$ & No \\
\hline Sweden & General law & Full amount & Yes & No & No \\
\hline Switzerland & $\begin{array}{l}\text { General law } \\
\text { (since 2010) }\end{array}$ & Full amount & Yes & $\begin{array}{l}\text { None, if repeat } \\
\text { offender } \geq 20 \% \\
\text { of tax }\end{array}$ & No \\
\hline \multirow[t]{2}{*}{ Turkey } & General law & Full amount & \multirow[t]{2}{*}{ Yes } & No & No \\
\hline & $\begin{array}{l}\text { Special program } \\
\text { in } 2009\end{array}$ & $\begin{array}{l}2 \% \text { or } 5 \% \text { of } \\
\text { tax base }\end{array}$ & & No & No \\
\hline United & General law & Full amount & \multirow[t]{2}{*}{ Varies } & Reduced & No \\
\hline Kingdom & $\begin{array}{l}\text { Special program } \\
\text { in } 2009 / 2010\end{array}$ & Full amount & & $10-20 \%$ of tax & No \\
\hline United & Special program & Full amount & Varies & $20 \%$ of tax, & No \\
\hline States & $2009,2011,2012$ & & & $\begin{array}{l}20-27.5 \% \text { of off- } \\
\text { shore balance }\end{array}$ & \\
\hline
\end{tabular}

Table based on information from OECD (2010b), updated with information from tax authority and tax consultancy homepages.

Table 2: Location of Foreign Bank Accounts, 2009 OVDP

\begin{tabular}{lrr}
\hline Country & Frequency & Percent \\
\hline Switzerland & 5,427 & $42 \%$ \\
United Kingdom & 1,058 & $8 \%$ \\
Canada & 556 & $4 \%$ \\
France & 528 & $4 \%$ \\
Israel & 510 & $4 \%$ \\
Germany & 484 & $4 \%$ \\
Hong Kong & 362 & $3 \%$ \\
Singapore & 156 & $1 \%$ \\
Cayman Islands & 148 & $1 \%$ \\
Isle of Man & 90 & $1 \%$ \\
Jersey & 72 & $1 \%$ \\
Bahamas & 69 & $1 \%$ \\
\hline
\end{tabular}

Locations of foreign bank accounts reported in the 2009 offshore voluntary disclosure program, selected countries. Data from U.S. Government Accountability Office (2014). 
Table 3: Accounts, Tax Payments and Penalties from 2009 OVDP

\begin{tabular}{lrrrrr}
\hline & Mean & 10th Pctl. & Median & 90th Pctl. & Total \\
\hline Offshore account balance & $1,923,310$ & 78,315 & 568,735 & $4,054,505$ & 28.9 bn \\
Tax and interest & 127,326 & 155 & 16,234 & 247,528 & 1.9 bn \\
OVDP penalty & 375,879 & 13,320 & 107,949 & 793,166 & 5.6 bn \\
\hline
\end{tabular}

Account balances, tax and penalty payments within 2009 OVDP for 2003-2008 in U.S.-\$. The account balance is an estimate for the highest balance between 2003 and 2008. Data from U.S. Government Accountability Office (2014), totals are own extrapolations.

Table 4: Foreign Asset Holdings of U.S. Residents

\begin{tabular}{llll}
\hline & 2006 & 2009 & 2012 \\
\hline Assets held abroad (total) & $\$ 3,205 \mathrm{bn}$ & $\$ 4,193 \mathrm{bn}$ & $\$ 4,132 \mathrm{bn}$ \\
Assets in offshore centers & $\$ 1,298 \mathrm{bn}$ & $\$ 1,634 \mathrm{bn}$ & $\$ 1,263 \mathrm{bn}$ \\
\hline
\end{tabular}

All variables are for U.S. residents. Source: BIS. 
Table 5: Difference-in-Difference Results

\begin{tabular}{lllll}
\hline & \multicolumn{1}{c}{$(1)$} & \multicolumn{1}{c}{$(2)$} & \multicolumn{1}{c}{$(3)$} & \multicolumn{1}{c}{$(4)$} \\
\hline \multirow{2}{*}{ Post } & $-233,315^{* *}$ & $-58,329^{* *}$ & $-453,809^{* * *}$ & 31,770 \\
& $(0.023)$ & $(0.022)$ & $(0.005)$ & $(0.521)$ \\
Treated & $935,885^{* *}$ & $233,971^{* *}$ & $-6,734,296^{* * *}$ & $933,892^{* * *}$ \\
& $(0.033)$ & $(0.032)$ & $(0.006)$ & $(0.005)$ \\
PostTreated & $468,476^{* *}$ & $117,119^{* *}$ & $688,970^{* * *}$ & 203,391 \\
& $(0.014)$ & $(0.018)$ & $(0.006)$ & $(0.148)$ \\
\hline Observations & 64 & 256 & 64 & 64 \\
$R^{2}$ & 0.117 & 0.108 & 0.173 & 0.093 \\
\hline
\end{tabular}

This table shows results from a DiD test that considers the acquisition of whistle-blower information on tax evaders by the German government in February 2010. The dependent variables are tax revenues of the self-reported income tax and various other taxes (Col. 1 and 2: capital income withholding tax; Col. 3: payroll tax; Col. 4: other withheld income taxes) of the 16 German states in thousand Euro, and Treated $=1$ indicates self-reported income tax revenues. Columns (1), (3) and (4) use tax revenues at the yearly level for 2009 and 2010, Col. (2) quarterly data from the same period. All regressions are run with an intercept. p-values are in parenthesis and are based on a wild cluster bootstrap (Cameron et al., 2008).*** and ${ }^{* *}$ indicate significance at the $1 \%$ and $5 \%$ level, respectively. Column (2) includes quarterly fixed effects. 